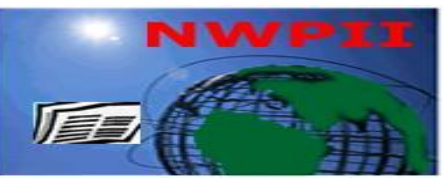

American Journal of Biomedical Sciences

ISSN: 1937-9080

nwpii.com/ajbms

\title{
General Characteristics of Human Neonate Immunity
}

\author{
Zhan $\mathrm{Qi}^{12}$, Wenjun Mou ${ }^{12}$, Jianxin $\mathrm{He}^{13}$, Jingang Gui ${ }^{12^{*}}$
}

${ }^{1}$ Key Laboratory of Major Diseases in Children by Ministry of Education, Beijing Children's Hospital, Capital Medical University, Beijing, PR China

${ }^{2}$ Laboratory of Immunology, Beijing Pediatric Research Institute, Beijing Children's Hospital, Capital

Medical University, Beijing, PR China

${ }^{3}$ Department of Pulmonary Medicine, Beijing Children's Hospital, Capital Medical University, Beijing, PR

China

*Corresponding author:

Jingang Gui, Ph. D.

Beijing Pediatric Research Institute

Beijing Children's Hospital

Capital Medical University

Beijing 100045, PR China

Email: guijingang@bch.com.cn

Received: 23 October 2014; | Revised: 20 November 2014; | Accepted: 18 December 2014

\begin{abstract}
Neonatal immune system inherits its immunosuppressive features derived from the mutual negotiation of immune status between fetus and mother during pregnancy. In the same time, an active immune arm has to be quickly established in newborns in the context of growing maturation to combat various threats that never existed in the intrauterine environment. These seemingly contradictive functional requirements build the unique characteristics of neonate immunity with regard to its cell components of both innate and adaptive system, immune polarity of cytokines, responsiveness to pathogens, relation to genetic factors, as well as the propensity of allergy. This review summarizes these factors and the characteristics of human neonate immunity, a defenses system in development yet very critical for newborns' health and survival.
\end{abstract}

Keywords: Neonate Immunity, Cytokine, Primary Immunodeficiency, Allergy.

\section{Introduction}

From a sterile intrauterine environment to an open environment full of different antigens never encountered before, neonatal immune system experiences a huge transition in the first several weeks after birth. Both fetuses and mothers develop an immunosuppressive property during pregnancy to avoid the pathologic inflammation through negotiating their mutual antigenic differences. On the other hand, neonates have to arm their defense system to counteract the abrupt influx of new pathogens immediately at birth. 
These seemingly contradictive requirements for the immune system comprise the unique features of neonate immunity [1]. Most of the components of the immune system are present at birth. However, an increasing body of evidence has strongly suggested that both innate and adaptive immunity in neonates are at their suboptimal conditions for elimination of pathogens [2]. In addition, there is an age-dependent maturation of neonate immunity [3].

Invading pathogens are constrained by coordinated actions of innate and adaptive immunity. The innate immune system is mainly comprised of macrophages, monocytes, NK cells and neutrophils that immediately confine pathogens at the site of infection. The adaptive immunity is responsible for pathogen elimination in late phase of infection as well as the formation of antigen-specific immunological memories. Toll-like receptors (TLRs) and cytokines determine the magnitude of early innate responses and bridge late antigenspecific adaptive immunity. This review will summarize the characteristics of these cell components and soluble factors particularly in neonates.

\section{Neutrophils}

Adequate phagocytic function of neutrophils is critical for control of microbial infections in neonates. The number of neutrophils reaches $13 \times 10^{9} / \mathrm{L}$ in peripheral blood within 12 hours after birth possibly resulting from the drastic stimulation of delivery. The neutrophils count goes down in the next 72 hours before it gradually brings to the level of adult [4]. Study on calf revealed that neutrophils are the predominant leukocytes in newborn animal and the cell count is four times of that in 3-week-old ones [5]. Despite of higher cell count of neutrophils, the phagocytosis of these devourers in neonates is much lower compared with older children and adults. The phagocytosis could be regulated by many factors such as colostrum from mother, the stresses associated with parturition [6], high blood cortisol levels at birth [7] and cell adhesion molecules ( $\beta 2$ integrin, L-selectin, etc.) critical for cell migration [8]. It has been reported that migration of neutrophils into tissues is impaired in neonates [2]. In addition, neutrophils from cord blood of neonates exhibited a reduced in vitro response to interleukin- 8 (IL-8) and other chemotactic cytokines [9].

\section{Monocytes/Macrophages}

In contrast to neutrophils, the number of circulating monocytes in neonates is similar to that in adults [10]. Nevertheless, the abilities of chemotaxis, adhesion, phagocytosis and cytotoxicity of these cells in neonates, particularly in preterm ones are much poorer than that in adults [4]. Macrophages in neonates show a diminished response to lipopolysaccharide (LPS) during the bacterial infection because they are not able to produce enough inflammatory cytokines such as IL-1 $\beta$, IL-12 and tumor necrosis factor alpha (TNF- $\alpha)[11,12]$. Instead, immunosuppressive cytokines such as IL-6 and IL-10 are produced at a much higher level by neonatal macrophages. Besides this, neonatal macrophages express reduced levels of CD14, TLR2 and TLR4 which are critical mediators in LPS and $S$. pneumoniae binding and recognition [13].

\section{NK cells}

Study on the cord blood of human neonates revealed that both the absolute number and percentage of NK cells are higher than those in adult peripheral blood [12]. The fact that preterm neonates have an increased risk for infections owning to a reduced NK cell percentage [14] emphasizes the critical role of neonatal NK cells in preventing early infections. The CD56-CD16+ NK cells are more abundant in neonates instead of more mature CD56+CD16+ NK cells, the major NK subset in adults [15]. It is well documented that neonatal NK cells have reduced capacity for recognizing and clearing pathogens [16]. Neonate NK cells show less direct cytotoxicity and antibody-dependent cellmediated cytotoxicity (ADCC) regardless the fact that there is an elevated expression of granzyme $\mathrm{B}$ and perforin. Spontaneous cytotoxicity of NK cells from purified cord blood against NK- 
sensitive targets is reduced compared with those isolated from adult peripheral blood [17]. The ADCC function of NK cells improves to adult level as a result of increasing IL-2 expression during the first year of life [4].

\section{Toll-Like Receptors}

TLRs are able to recognize and bind to the invading microbial pathogens. There are 10 TLR family members being identified in human and each one recognizes a number of ligands, such as LPS, porin and peptidoglycan [18]. All TLRs are transmembrane proteins with cytoplasmic Toll/IL-1 receptor domain [19]. Working together with certain adapters, TLRs are able to activate immune cell signaling cascades that regulate the initiation and activation of innate and adaptive immunity [20]. Both mRNAs and proteins of TLRs and adapters discovered so far are detectable in neonates [21]. It has been shown that the TLR4 expression begins before birth and its expression level is largely reduced in preterm neonates than that in full-term ones [22]. The expression regulation of different TLRs could be very different during microbial infections in neonates. For example, TLR2 is significantly increased during the neonatal sepsis while TLR4 remains unchanged [21]. In addition, neonatal monocytes generally produce a higher IL-6/TNF$\alpha$ ratio in response to TLR-mediated signaling [23]. The monocytic production of TNF- $\alpha$ after TLR1/2, TLR2/6, TLR4 and TLR7 activation was revealed 10-1000 folds higher in adults relative to neonates [24].

\section{T Cells}

There is a transitory period in newborns characterized by an absence of memory $\mathrm{T}$ cells and a slow adaptive immune response with tolerance features [25]. The number of $\mathrm{T}$ cells in fetus rises up from the third-month in uterus and starts to decrease after the delivery; a decrease lasts for the next 6 months. Majority of T cells in neonates are still in their naive status marked by the expression of CD45RA and lack of CD45RO. The activated CD25+ T cells in neonates, beside their lower number compared to adults, possess an attenuated potential for initiation of primary immune response [26, 27]. While a comparable IL-2 production by neonatal T-cell is observed upon activation, it is clearly evident that interferon gamma (IFN- $\gamma$ ) and TNF- $\alpha$ are significantly reduced as compared to adult T-cell. It is possibly just a reflection of a shortage of memory $\mathrm{T}$ cells rather than a result of faulty development or dysfunction of neonatal $\mathrm{T}$ cells [28]. Although few $\mathrm{T}$ cells present in the spleens in the first week of life, $\mathrm{T}$ cells especially the Th2-type ones preferentially develop in neonatal spleens [29]. It has been proved that neonatal $\mathrm{T}$ cells skew to Th2 differentiation and are defective in developing protective Th1-type responses. This at least in part accounts for the susceptibility to infectious agents and the propensity to allergic diseases in neonates. Compared with $\alpha \beta T$ cells, $\gamma \delta \mathrm{T}$ cells are of disproportionately importance in immune defense of neonates. Neonatal $\gamma \delta$ T cells acquire a strong, pleiotropic functional responsiveness, and are exempted from IFN- $\gamma$ deficiency neonatal $\alpha \beta \mathrm{T}$ cells exhibited. Susceptible to viral infections and suboptimal cytokine responses in preterm newborns are believed to have relation to impaired expression of TLR3 and TLR7 on $\gamma \delta \mathrm{T}$ cells that otherwise at normal level in term neonates [30]. Th17 cells were recently found to be an important mediator for combating bacterial and fungal infections. Study on human neonates revealed a higher expression levels of IL-23R, RORt, and STAT3 prior to activation, all of which contribute to the Th17 bias upon activation [31]. The presence of IL-2 along with TGF$\beta$ exclusively drives neonatal naive $\mathrm{T}$ cells to differentiate into $\mathrm{T}$ regulatory cells (Tregs) [32]. Tregs are present at high frequency in neonatal lymph nodes and in human cord blood [33, 34]. These neonatal Tregs are capable to mediate immunological self-tolerance and quell various immune responses [35]. CD8+ $\mathrm{T}$ cell are potent in host defense against virus infection and intracellular pathogens [36]. Neonatal CD8+ T cell activation is significantly repressed compared with that in adults owing to low expression of IL12 [37]. Other studies, however, have demonstrated that DNA vaccines given at birth resulted in a rapid induction of adult-like 
protective antigen-specific $\mathrm{CD} 8+\mathrm{T}$ cell responses in terms of cytokine profile and effector functions within neonatal life [38].

\section{B Cells and Immunoglobulins}

B-1 and B-2 cells are the two main subsets of B lymphocytes. B-1 cells are defined as part of the innate immune system and produce immunoglobulins (Igs). B-2 cells exist in the secondary lymphoid organs and are believed to be the major B-cell subset responsible for adaptive immunity, which can undergo Ig class switching and differentiate into memory cells [39]. It is still a mystery why the level of B-1 common lymphoid progenitors in neonatal bone marrow is much higher in comparison with adults [40]. B-cell responses such as to polysaccharide antigens are relatively low in neonates due to decreased intrinsic ability of macrophages to promote regular B-cell functions [41]. In addition, neonatal $\mathrm{T}$-cell expresses a reduced level of CD40L, an important ligand for CD40 on B-cell to aid Ig class switching. As a consequence, neonatal B-cell has a subdued Ig class switching upon activation which leads to a decrease in $\operatorname{IgG}$ and $\operatorname{Ig} \mathrm{A}$ production relative to adults [42].

Due to the immaturity of endogenous B-cell function, transfer of passive immunity especially Igs from mother is of paramount importance for neonate survival. Maternal Igs are able to pass to neonates either in utero, or through ingestion of Ig-rich colostrum by neonates [43, 44]. IgGs transport through placenta beginning with IgG1 followed by $\operatorname{IgG} 4, \operatorname{IgG} 3$, and $\mathrm{IgG} 2$ during the trimester of the pregnancy. IgG levels in cord blood of preterm infants had been shown to be much lower than that in term ones [45]. The maternal IgG including antigen-specific IgG starts to transfer across the placenta from the maternal circulation as early as 32 weeks of gestation. Maternal IgG is still detectable until 12-18 months after birth, while IgG production is sharply produced by infant first few months, reaching to adult level in the following 2-7 years [46]. Both the colostrum and mature breast milk contain high level of secretory $\operatorname{IgA}(\operatorname{sg} \mathrm{A})$, which confers immune protection to neonates before full maturation of immunity. While $\operatorname{sIgA}$ is the predominant antibody, human milk also contains IgM and IgG, the latter becoming more abundant in later lactation [47]. To be noted, sIgA also plays an immunosuppressive role to inhibit proinflammatory gastrointestinal responses to oral antigens [48]. Besides protective roles, maternal antibodies unfortunately have adverse effects for neonates in some occasions. For example, autoantibodies created by maternal auto-reactive B cells passing through the placenta lead to a poor health outcome of newborns [49]. In addition, presumed protective maternal antibodies are likely to inhibit infants' immune responses to vaccines through various possible mechanisms [50]. Conversely, recent data demonstrated that a sufficient B-cell function to mount broadly neutralizing antibodies against HIV-1 could be successfully elicited in HIV-1-infected infants [51]. Therefore, it is implied that the concept of relative weak vaccine responses in neonates presumably attributed to immature B-cell function and maternal antibodies inhibition might require adjustment according to different episodes.

\section{Cytokines}

Cytokines regulate innate immunity and connect the innate immunity with antigenspecific adaptive immunity [52]. Neonate immunity is characterized by a decrease in IFN- $\gamma$, IL-12, IL-18, and TNF- $\alpha$, and an increase in IL$1 \beta$, IL-6, IL-23 and IL-10 [52, 53]. Th1 cytokines, including IL- 2 and IFN- $\gamma$, are able to stimulate cell-mediated immunity. IL-4, main representative of Th2 cytokines, plays a key role in inducing B-cell differentiation and is associated with allergy [41]. It has been known that the main character of cytokines polarity distinguishing neonates from adults is the Th2biased immune response [28]. Following stimulation in culture, neonate monocytes express reduced TNF- $\alpha$ relative to adults $[29,54]$. On the contrary, expression of IL-8 and TLR4 in monocytes is greater in neonates than in adults [55]. Cytokine levels, generally being stable in the first week of life, are greatly influenced by the maturity of immune system as well as the 
activation of immune components by infections. Levels of many cytokines, cytokine antagonists or chemokines, including IL-1R $\alpha$, IL-2, IL-6, IL8, IL-10, IL-12, IL-13, IL-15, IL-17, TNF- $\alpha$, IFN- $\gamma$, and MCP-1, are much lower in preterm neonates compared to term ones [56]. Those cytokines unable to cross placental barrier, such as IL-1, IL-6 and TNF- $\alpha$, are found elevated in umbilical cord blood during infections, especially in neonatal sepsis [57]. Rapid change of blood cytokines levels before acute phase of sepsis is a prognostic alarm for the oncoming threat [58]. IL-1 $\beta$, IL-6, IL-8, IL-2 soluble receptor (SIL2R) and TNF- $\alpha$ have been observed to increase in neonates with bacterial infection. These increases in cytokines occur before the clinical presentation and the laboratory confirmation of sepsis [59].

\section{Primary Immunodeficiencies}

It is no doubt that the genetic factor is one of the main determinants for immune function. Neonates with immunodeficiency caused by genetic mutations might show no signs of illness possibly because of functional compensation by antibodies passively transferred from healthy mother. However, many young infants and children who suffered from recurrent infections, or complications after being given to Bacillus Calmette-Guerin vaccine were eventually found to have primary immunodeficiencies (PIDs) [60]. PIDs is referred as a heterogeneous group of over 200 different disorders that result from genetic defects in the development, function, or both of immunity [61]. PIDs result in a wide range of clinical symptoms including but not limited to allergy, persistent infections, inflammation, autoimmunity, and other malignancies. Although PIDs affect all age groups [62], major efforts are taken to develop new methods for detection of PIDs in the neonatal period [61]. Laboratory diagnostic measurement of serum immunoglobulin, complete blood counts, respiratory burst assay, T-cell proliferation, T-cell receptor (TCR) rearrangement excision circles (TRECs) and TCR V $\beta$ chain usage are currently used for screening PIDs [63]. PIDs can be broadly classified depending on which component of the immune system is affected.
Antibody-mediated, T-cell and combined, phagocyte, as well as complement deficiencies are the most common types [64].

\section{Antibody-mediated deficiencies}

Antibody-mediated deficiencies, the most common type of PIDs, account for almost $55 \%$ of all PIDs diagnoses according to the European Society for Immunodeficiencies (ESID) registry [65]. Patients with antibody-mediated deficiencies usually show symptoms 6 months after birth with recurrent sinopulmonary infections by encapsulated bacteria [66]. Approximately $20 \quad$ antibody-mediated deficiencies have been discovered to date, and the typical disorders include Bruton's agammaglobulinemia (X-linked agammaglobulinemia, XLA), common variable immunodeficiency (CVID), selective $\operatorname{IgA}$ deficiency, specific antibody deficiency and IgG subclass deficiency [67]. Patients afflicted with XLA are characterized by limited circulating B cells and low levels of serum $\mathrm{IgG}, \operatorname{IgA}$ and $\mathrm{IgM}$. Genetic alterations in the Bruton's tyrosine kinase $(B T K)$ gene are responsible for most XLA cases, causing defects in B-cell development and maturation [68]. Although most CVID patients have normal number of circulating $B$ lymphocytes, serum IgG and at least one of IgM or $\operatorname{IgA}$ isotypes are reported lower than normal in a large proportion of patients [69].

\section{T-cell and combined deficiencies}

T-cell deficiencies account for $9 \%$ of PIDs in the ESID registry [65]. T-cell deficiencies usually present early in life, and most of them are characterized by severe combined immunodeficiency (SCID) with life-threatening infections and failure to thrive [70]. Omenn syndrome (OS) [71] is one type of SCIDs characterized by symptoms of erythroderma, hepatosplenomegaly, hypogammaglobulinemia, uniformly eosinophilia, alopecia, elevated serum $\operatorname{IgE}$, and oligoclonal TCR repertoire. OS could be a result from partial $\mathrm{V}(\mathrm{D}) \mathrm{J}$ recombination activity due to missense mutation of $R A G 1$ or RAG2 genes [72], 
or a mutation of $I L-7 R A$ gene [73]. Other novel types of SCIDs are continuously being identified. X-linked immunodeficiency with $\mathrm{Mg} 2+$ defect, Epstein-Barr virus (EBV) infection, and neoplasia disease (XMEN) exemplifies the fact that some worse conditions of PIDs can be restricted through good health management without gene therapy or stem cell transplantation. The NK cells and CD8+ T cells in XMEN patient exhibit impaired cytolytic responses against EBV due to a defective expression of $\mathrm{NKG} 2 \mathrm{D}$, a consequence of decreased intracellular free $\mathrm{Mg} 2+$ due to MAGT1 mutation. Magnesium supplementation in XMEN patients restored the intracellular $\mathrm{Mg} 2+$ and $N K G 2 D$ expression which concurrently reduced the EBV-infected cells in vivo [74].

\section{Phagocyte deficiencies}

Phagocyte deficiencies are the result of abnormalities in dendritic cells, neutrophils or macrophages, which account for $12.5 \%$ of primary immunodeficiency diseases in the ESID registry [65]. The symptoms of recurrent pyogenic bacterial/fungal infections or septicemia are the suspicious elements for phagocyte deficiencies [75]. Chronic granulomatous disease, hyper-IgE syndrome and leukocyte adhesion deficiency type-1 (LAD-1) [76, 77] are typical phagocytic deficiencies commonly present in the first few weeks of newborns. Chronic granulomatous disease is the most common phagocytic disorder caused by mutations in the NADPH oxidase [78]. Hyper-IgE syndrome is a phagocytic deficiency characterized by extremely high levels of serum IgE levels, and dominantnegative mutations in STAT3 were found to be responsible for most cases [79]. LAD1 is a rare inherited phagocytic deficiency caused by mutations in the gene encoding $\beta 2$ integrin [80].

\section{Complement deficiencies}

Of all PIDs, complement deficiencies represent no more than $1 \%$ of identified cases. Patients with these disorders readily become victims of recurrent infections or systemic autoimmune diseases [75]. Complement deficiencies may involve deficiency in early complement pathway components (C1q, C1r, C2, and $\mathrm{C} 4$ ), late complement pathway components (C5, C6, C7, C8, and C9) or C3 and regulatory components [81].

\section{Allergy}

Allergy is one of the most common diseases in children, such as asthma and food allergy. Clinical presentations of allergy is rarely observed in the first month after birth. However, the status of being allergic is determined by various factors as early as during the pregnancy [82, 83]. Many allergens can transmit through placenta and antigen-specific $\mathrm{T}$ cells can be detected in the neonatal cord blood. It has been observed that high concentration of soluble form of CD14 (sCD14) in amniotic fluid reduced the risk of atopic dermatitis in newborns. Infants fed with breast milk containing low levels of sCD14 had a higher risk of subsequent allergy, suggesting that the protective effect of breast milk may be mediated through innate immune mechanisms [84]. In addition, polymorphism in TLR4 gene which down-regulates the function of CD14 or TLR4 in newborns was linked with a reduced risk of allergy and an alleviated severity of the disease [85]. Prenatal exposures to animal species, stables and barns prevent children from atopic diseases possibly through inducing antiTh2 immune phenotype as well as regulating TLR signaling pathways [86, 87]. In addition, both cell count and function of Tregs in cord blood are up-regulated in neonates born to the farming mothers compared to those born to nonfarming mothers. The decreased number in Tregs is believed to be responsible for the development and progression of allergy [88]. Interestingly, caesarean delivery is proved to have relationship with increased risk of asthma and allergic diseases, which is attributed to different gastrointestinal microbial colonization at birth compared to those delivered vaginally [89]. Cow's milk allergy (CMA), also defined as cow's milk protein allergy, is the most common allergy in newborns especially for formula-fed infants [90]. CMA is associated with higher risk of other allergic conditions, such as asthma, atopic 
eczema, and egg allergy [91]. Neonates with CMA always present an increased production of Th2 cytokines IL-4 and IL-13, which promotes Ig class switching and IgE secretion by plasma cells [92, 93]. Suppression of Tregs by inhibitory cytokines such as IL-10 and TGF- $\beta$ is one of the possible mechanisms contributing to CMA formation [91]. Meanwhile, colostrum and breast milk contain a variety of molecules including the most abundant sIgA which can influence immune responses in the gut-associated lymphoid tissue of neonates [93]. The low level of both cow-milkspecific and total IgA in colostrum or breast milk is associated with increased risk of CMA development [94].

\section{Conclusion}

Neonate immunity is vital for newborns' health and survival and its unique features distinguished from adults are the main determinant for many characteristics of infants and children's diseases. The Th2 cytokine polarity and low responsiveness to pathogens, immune-related gene mutations, and prenatal antigen experiences of both innate and adaptive immunity inscribe neonates' susceptibility to infectious agents as well as the propensity to allergens. Increasing body of data on neonate immunity are acquired through comparison between neonates cord blood and adults' peripheral blood, in addition to studies on preterm infants. However, these accomplishments could not conceal our naivety for understanding this enigmatic defense system that seems vulnerable yet can fulfill 'just enough' functions for infant survival, leaving an enough plasticity for immune educating through counteracting with different episode of pathogenic invasion each individual neonate encounters.

\section{Acknowledgement}

This work is supported by a Startup Research Fund by Beijing Children's Hospital to JG.

\section{References}

1. Makrigiannakis, A.; Karamouti, M.; Drakakis, P.; Loutradis, D.; Antsaklis, A. Fetomaternal immunotolerance, American journal of reproductive immunology, 2008, 60(6), 482-496. DOI: 10.1111/j.16000897.2008.00655.x

2. Firth, M.A.; Shewen, P.E.; Hodgins, D.C. Passive and active components of neonatal innate immune defenses, Animal health research reviews, 2005, 6 (2), 143-158. DOI:http://dx.doi.org/10.1079/AHR2005107

3. Adkins, B.; Leclerc, C.; Marshall-Clarke, S. Neonatal adaptive immunity comes of age, Nature reviews Immunology, 2004, 4(7), 553564. DOI:10.1038/nri1394

4. Marshall-Clarke, S.; Reen,D.; Tasker, L.; Hassan, J. Neonatal immunity: how well has it grown up? Immunol Today, 2000, 21 (1), 35-41. DOI:10.1016/S0167-5699(99)01548-0

5. Menge, C.; Neufeld, B.; Hirt, W.; Schmeer, N.; Bauerfeind, R.; Baljer, G.; Wieler, L.H. Compensation of preliminary blood phagocyte immaturity in the newborn calf, Veterinary immunology and immunopathology, 1998, 62 (4), 309-321. DOI:10.1016/S0165-2427(98)00109-3

6. Thilaganathan, B.; Makrydimas, G.; Plachouras, N.; Nicolaides, K.H. Neutrophil and monocyte beta 2-integrin expression in maternal and fetal blood, Am J Obstet Gynecol, 1995, 172 (1 Pt 1), 58-62. DOI:10.1016/0002-9378(95)90084-5

7. Muniz-Junqueira, M.I.; Mota, L.M.; Aires, RB.; Junqueira, LF. Digitalis inhibits and furosemide does not change the in vitro phagocytic function of neutrophils of healthy subjects, Int Immunopharmacol, 2003, 3 (1011), 1439-1445. DOI:10.1016/S15675769(03)00142-5

8. Lee, E.K.; Kehrli, M.E. Expression of adhesion molecules on neutrophils of periparturient cows and neonatal calves, American journal of veterinary research, 1998, 59 (1), 37-43.

9. Fox, S.E.; Lu, W.; Maheshwari, A.; Christensen, R.D.; Calhoun, D.A. The effects and comparative differences of neutrophil 
specific chemokines on neutrophil chemotaxis of the neonate, Cytokine, 2005, 29 (3), 135-140. DOI:10.1016/j.cyto.2004.10.007

10. Flaminio, M.J.; Rush, B.R.; Davis, E.G.; Hennessy, K.; Shuman, W.; Wilkerson, M.J. Characterization of peripheral blood and pulmonary leukocyte function in healthy foals, Veterinary immunology and immunopathology, 2000, 73 (3-4), 267-285. DOI:10.1016/S0165-2427(00)00149-5

11. Bondada, S.; Wu,H.; Robertson, D.A.; Chelvarajan, R.L. Accessory cell defect in unresponsiveness of neonates and aged to polysaccharide vaccines, Vaccine, 2000, 19 (4-5), 557-565. DOI:10.1016/S0264410X(00)00161-4

12. Peoples, J.D.; Cheung, S.; Nesin, M.; Lin, H.; Tatad, A.M.; Hoang, D.; Perlman, J.M.; Cunningham-Rundles, S. Neonatal cord blood subsets and cytokine response to bacterial antigens, Am J Perinatol, 2009, 26 (9), 647657. DOI: $10.1055 / \mathrm{s}-0029-1220788$

13. Chelvarajan, R.L.; Collins, S.M.; Doubinskaia, I.E.; Goes, S.; Van Willigen, J.; Flanagan, D.; De Villiers, W.J.; Bryson, J.S.; Bondada, S. Defective macrophage function in neonates and its impact on unresponsiveness of neonates to polysaccharide antigens, J Leukoc Biol, 2004, 75 (6), 982-994. DOI:10.1189/jlb.0403179

14. Ma, L.; Chen, R.; Liu, F.; Li, Y.; Wu, Z.; Zhong, W.; Lu, G.; Wang, B. Reduced NK cell percentage at birth is associated with late onset infection in very preterm neonates, Scand J Immunol, 2014, 80 (1), 50-56. DOI: $10.1111 / \mathrm{sji} .12181$

15. Gaddy, J.; Broxmeyer, H.E. Cord blood CD16+56- cells with low lytic activity are possible precursors of mature natural killer cells, Cell Immunol, 1997, 180 (2), 132-142. DOI:10.1006/cimm.1997.1175

16. Dalle, J.; Menezes, J.; Wagner, E.; Blagdon, M.; Champagne, J.; Champagne, M.A.; Duval, M. Characterization of cord blood natural killer cells: implications for transplantation and neonatal infections, Pediatr Res, 2005, 57(5 Pt 1), 649-655. DOI:10.1203/01.PDR.0000156501.55431.20
17. Guilmot, A.; Hermann, E.; Braud, V.M.; Carlier, Y.; Truyens, C. Natural killer cell responses to infections in early life, J Innate Immun, 2011, 3 (3), 280-288. DOI: $10.1159 / 000323934$

18. Fleer, A. K.T. Innate immunity: toll-like receptors and some more. A brief history, basic organization and relevance for the human newborn, Neonatology, 2007, 92 (3), 145-157. DOI:10.1159/000102054

19. O'Neill, L.A. How Toll-like receptors signal: what we know and what we don't know, Curr Opin Immuno, 2006, 18 (1), 3-9. DOI:10.1016/j.coi.2005.11.012

20. Bell, J.K.; Mullen, G.E.; Leifer, C.A.; Mazzoni, A.; Davies, D.R.; Segal, D.M. Leucine-rich repeats and pathogen recognition in Toll-like receptors, Trends Immunol, 2003, 24 (10), 528-33. DOI:10.1016/S1471-4906(03)00242-4

21. Viemann, D.; Dubbel, G.; Schleifenbaum, S.; Harms, E.; Sorg, C.; Roth, J. Expression of toll-like receptors in neonatal sepsis, Pediatr Res, 2005, 58 (4), 654-659. DOI:10.1203/01.PDR.0000180544.02537.FD

22. Förster-Waldl E, Sadeghi, K.; Tamandl, D.; Gerhold, B.; Hallwirth, U.; Rohrmeister, K.; Hayde, M.; Prusa, A.R.; Herkner, K.; BoltzNitulescu, G.; Pollak, A.; Spittler, A. Monocyte toll-like receptor 4 expression and LPS-induced cytokine production increase during gestational aging, Pediatr Res, 2005, $58 \quad$ (1), 121-124. DOI:10.1203/01.PDR.0000163397.53466.0F

23. Angelone, D.F.; Wessels. M.R.; Coughlin, M.; Suter, E.E.; Valentini, P.; Kalish, L.A.; Levy, O. Innate immunity of the human newborn is polarized toward a high ratio of IL-6/TNF- $\alpha$ production in vitro and in vivo, Pediatr Res, 2006, 60 (2), 205-209. DOI:10.1203/01.pdr.0000228319.10481.ea

24. Levy, O.; Zarember, K.A.; Roy, R.M.; Cywes, C.; Godowski, P.J.; Wessels, M.R. Selective impairment of TLR-mediated innate immunity in human newborns: neonatal blood plasma reduces monocyte TNF-alpha induction by bacterial lipopeptides, lipopolysaccharide, and imiquimod, but preserves the response to R-848, Journal of 
immunology, 2004, 173 (7), 4627-4634.DOI $: 10.4049 /$ jimmunol.173.7.4627

25. Bilbo, S.D.; Biedenkapp, J.C.; Der-Avakian, A.; Watkins, L.R.; Rudy, J.W.; Maier, S.F. Neonatal infection-induced memory impairment after lipopolysaccharide in adulthood is prevented via caspase-1 inhibition, J Neurosci, 2005, 25(35), 80008009. DOI: $10.1523 /$ JNEUROSCI.1748$\underline{05.2005}$

26. Luciano, A.A.; Yu, H.; Jackson, L.W.; Wolfe,

L.A.; Bernstein, H.B. Preterm labor and chorioamnionitis are associated with neonatal $\mathrm{T}$ cell activation, PLoS One, 2011, 6(2):e16698. 10.1371/journal.pone.0016698

27. Adkins, B. T-cell function in newborn mice and humans, Immunol Today, 1999, 20 (7), 330-335. DOI:10.1016/S01675699(99)01473-5

28. Debock, I.; Flamand, V. Unbalanced Neonatal CD4(+) T-Cell Immunity, Front Immunol, 2014, 5 (5), 393. DOI: 10.3389/fimmu.2014.00393.eCollection 2014

29. Adkins, B.; Bu, Y.; Cepero, E.; Perez, R. Exclusive Th2 primary effector function in spleens but mixed Th1/Th2 function in lymph nodes of murine neonates, Journal of immunology, 2000, 164 (5), 2347-2353. DOI: $\underline{10.4049 / j i m m u n o l .164 .5 .2347 ~}$

30. Gibbons, D.L.; Haque, S.F., Silberzahn, T.; Hamilton, K.; Langford, C.; Ellis, P.; Carr, R.; Hayday, A.C. Neonates harbour highly active gammadelta $\mathrm{T}$ cells with selective impairments in preterm infants, Eur $J$ Immunol, 2009, 39(7), 1794-1806. DOI: $10.1002 /$ eji.200939222

31. Black, A.; Bhaumik, S.; Kirkman, R.L.; Weaver, C.T.; Randolph, D.A. Developmental regulation of Th17-cell capacity in human neonates, Eur J Immunol, 2012, 42(2), 311-319. DOI: $10.1002 /$ eji.201141847

32. Zheng SG. Regulatory $\mathrm{T}$ cells vs Th17: differentiation of Th17 versus Treg, are the mutually exclusive? Am $J$ Clin Exp Immunol.,2013 Feb 27;2(1):94-106.
33. Burt TD. Fetal regulatory $\mathrm{T}$ cells and peripheral immune tolerance in utero: implications for development and disease, $A m$ J Reprod Immunol. 2013 Apr;69(4):346-58. DOI: $10.1111 /$ aji.12083

34. Michaëlsson J1, Mold JE, McCune JM, Nixon DF. Regulation of $\mathrm{T}$ cell responses in the developing human fetus, J Immunol. 2006 May 15;176(10):5741-8. DOI: 10.4049/jimmunol.176.10.5741

35. Teles A, Zenclussen AC, Schumacher A. Regulatory T cells are baby's best friends, $A m$ $J$ Reprod Immunol. 2013 Apr;69(4):331-9. DOI: 10.1111/aji.12067

36. Barry M, Bleackley RC. Cytotoxic T lymphocytes: all roads lead to death, Nat Rev Immunol. $2002 \quad$ Jun;2(6):401-9. DOI:10.1038/nri819

37. Lee HH, Hoeman CM, Hardaway JC, Guloglu FB, Ellis JS, Jain R, Divekar R, Tartar DM, Haymaker CL, Zaghouani H. Delayed maturation of an IL-12-producing dendritic cell subset explains the early Th2 bias in neonatal immunity, $J$ Exp Med. 2008 Sep 29;205(10):2269-80. DOI: $10.1084 /$ jem.20071371

38. Zhang J1, Silvestri N, Whitton JL, Hassett DE. Neonates mount robust and protective adult-like CD8(+)-T-cell responses to DNA vaccines, J Virol. 2002 Dec;76(23):11911-9. DOI: 10.1128/JVI.76.23.11911-11919.2002

39. Alugupalli, K.R.; Gerstein, R.M. Divide and conquer: division of labor by B-1 B cells, Immunity, 2005, $23 \quad$ (1), 1-2. DOI:10.1016/j.immuni.2005.07.001

40. Baumgarth, N. The double life of a B-1 cell: self-reactivity selects for protective effector functions, Nat rev Immunol, 2011,11 (1), 3446. DOI:10.1038/nri2901

41. Vigano, A.; Esposito, S.; Arienti, D.; Zagliani, A.; Massironi, E.; Principi, N.; Clerici, M. Differential development of type 1 and type 2 cytokines and beta-chemokines in the ontogeny of healthy newborns, Biol Neonate, 1999, 75 (1), 1-8. DOI: $\underline{10.1159 / 000014071}$

42. Barber, C.L.; Montecino-Rodriguez, E.; Dorshkind, K. Reduced production of B-1specified common lymphoid progenitors 
results in diminished potential of adult marrow to generate B-1 cells, Proceedings of the National Academy of Sciences of the United States of America, 2011, 108 (33), 13700-13704. DOI: 10.1073/pnas. 1107172108

43. Nonoyama, S.; Penix, L.A.; Edwards, C.P.; Lewis, D.B.; Ito, S.; Aruffo, A.; Wilson, C.B.; Ochs, H.D. Diminished expression of CD40 ligand by activated neonatal T cells, $J$ Clin Invest, 1995, 95 (1), 66-75. DOI:10.1172/JCI117677.

44. Hanson, L.A.; Ahlstedt, S.; Andersson, B.; Carlsson, B.; Fallstrom, S.P.; Mellander, L.; Porras, O.; Soderstrom, T.; Eden, C.S. Protective factors in milk and the development of the immune system, Pediatrics, 1985, 75 (1 Pt 2), 172-176.

45. Butler, J.E.; Lager, K.; Splichal, I.; Francis, D.; Kacskovics, I.; Sinkora, M.; Wertz, N.; Sun, J.; Zhao, Y.; Brown, W.R.; DeWald, R.; Dierks, S.; Muyldermans, S.; Lunney, J.K.; McCray, P.B.; Rogers C.S.; Welsh, M.J.; Navarro, P.; Klobasa, F.; Habe, F.; Ramsoondar, J. The piglet as a model for B cell and immune system development, Veterinary immunology and immunopathology, 2009, 128 (1-3), 147-170. DOI:10.1016/j.vetimm.2008.10.321

46. Kane, S.V.; Acquah, L.A. Placental transport of immunoglobulins: a clinical review for gastroenterologists who prescribe therapeutic monoclonal antibodies to women during conception and pregnancy, $A m \quad J$ Gastroenterol , 2009, 104 (1), 228-233. DOI:10.1038/ajg.2008.71

47. Janeway, C.; Walport, M.; Capra, J.D. Immunobiology: The immune system in health and disease.4th. Taylor \& Francis Inc.: London, 1999.

48. Gao, X.; McMahon, R.J.; Woo, J.G.; Davidson, B.S.; Morrow, A.L.; Zhang, Q. Temporal changes in milk proteomes reveal developing milk functions, J Proteome Res, 2012, $11 \quad$ (7), 3897-3907. DOI: $10.1021 / \mathrm{pr} 3004002$

49. Borchers, A.T.; Naguwa, S.M., Keen, C.L.; Gershwin, M.E. The implications of autoimmunity and pregnancy, J Autoimmun,
2010, $34 \quad$ (3), $\quad$ J287-299.

DOI:10.1016/j.jaut.2009.11.015

50. Siegrist, C.A. Mechanisms by which maternal antibodies influence infant vaccine responses: review of hypotheses and definition of main determinants, Vaccine, 2003, 21 (24), 34063412. DOI:10.1016/S0264-410X(03)00342-6

51. Goo, L.; Chohan, V.; Nduati, R.; Overbaugh, J. Early development of broadly neutralizing antibodies in HIV-1-infected infants, Nat Med, 2014, $20 \quad$ (6), 655-658. DOI:10.1038/nm.3565

52. Nesin, M.; Cunningham-Rundles, S. Cytokines and neonates, Am J Perinatol, 2000, 17 (8), 393-404. DOI: 10.1055/s-2000$\underline{13457}$

53. Maródi, L. Innate cellular immune responses in newborns, Clin Immunol, 2006,118 (2-3), 137-144. DOI:10.1016/j.clim.2005.10.012

54. Holt, P.G.; Jones, C.A. The development of the immune system during pregnancy and early life, Allergy, 2000, 55 (8), 688-697. DOI: 10.1034/j.1398-9995.2000.00118.x

55. Strunk, T.; Doherty, D.; Jacques, A.; Simmer, K.; Richmond, P.; Kohan, R.; Charles, A.; Burgner, D. Histologic chorioamnionitis is associated with reduced risk of late-onset sepsis in preterm infants, Pediatrics, 2012, 129 (1), e134-e141. DOI: 10.1542/peds.2010-3493

56. Levy, E.; Xanthou, G.; Petrakou, E.; Zacharioudaki, V.; Tsatsanis, C.; Fotopoulos, S.; Xanthou, M. Distinct roles of TLR4 and CD14 in LPS-induced inflammatory responses of neonates, Pediatr Res, 2009, 66 (2), 179-84. DOI:10.1203/PDR.0b013e3181a9f41b

57. Lusyati, S.; Hulzebos, C.V.; Zandvoort, J.; Sauer, P.J. Levels of 25 cytokines in the first seven days of life in newborn infants, BMC Res Notes, 2013, 20 (6), 547. DOI:10.1186/1756-0500-6-547

58. Shah, B.A.; Padbury, J.F. Neonatal sepsis: an old problem with new insights, Virulence, 2014, 5 (1), 170-178. DOI: $10.4161 /$ viru. 26906

59. Prendergast, A.J.; Klenerman, P.; Goulder, P.J. The impact of differential antiviral immunity in children and adults, Nat Rev 
Immunol, 2012, $12 \quad$ (9), 636-648. DOI:10.1038/nri3277

60. Norouzi, S.; Aghamohammadi, A.; Mamishi, S.; Rosenzweig, S.D.; Rezaei, N. Bacillus Calmette-Guérin (BCG) complications associated with primary immunodeficiency diseases, J Infect, 2012, 64 (6), 543-554. DOI: 10.1016/j.jinf.2012.03.012

61. Borte, S.; von Döbeln, U.; Fasth, A.; Wang, N.; Janzi, M.; Winiarski, J.; Sack, U.; PanHammarström, Q.; Borte, M.; Hammarström, L. Neonatal screening for severe primary immunodeficiency diseases using highthroughput triplex real-time PCR, Blood, 2012, 119 (11), 2552-2555. DOI: 10.1182/blood-2011-08-371021

62. Carneiro-Sampaio, M.; Moraes-Vasconcelos, D.; Kokron, C.M.; Jacob, C.M.; ToledoBarros, M.; Dorna, M.B.; Watanabe, L.A.; Marinho, A.K.; Castro, A.P.; Pastorino, A.C.; Silva, C.A.; Ferreira, M.D.; Rizzo, L.V.; Kalil, J.E.; Duarte, A.J. Primary immunodeficiency diseases in different age groups: a report on 1,008 cases from a single Brazilian reference center, J Clin Immunol, 2013, 33 (4), 716-724. DOI: 10.1007/s10875013-9865-6

63. McCusker, C.; Warrington, R. Primary immunodeficiency, Allergy Asthma Clin Immunol, 2011, 7 Suppl 1 (s11), S11. DOI: 10.1186/1710-1492-7-S1-S11

64. International Union of Immunological Societies Expert Committee on Primary Immunodeficiencies; Notarangelo, L.D.; Fischer, A.; Geha, R.S.; Casanova, J.L.; Chapel, H.; Conley, M.E.; CunninghamRundles, C.; Etzioni, A.; Hammartröm, L.; Nonoyama, S.; Ochs, H.D.; Puck, J.; Roifman, C.; Seger, R.; Wedgwood, J. Primary immunodeficiencies: 2009 update, $J$ Allergy Clin Immunol, 2009, 124 (6), 11611178. DOI: 10.1016/j.jaci.2009.10.013

65. Gathmann, B.; Grimbacher, B.; Beauté, J.; Dudoit, Y.; Mahlaoui, N.; Fischer, A.; Knerr, V.; Kindle, G.; ESID Registry Working Party. The European internet-based patient and research database for primary immunodeficiencies: results 2006-2008, Clin
Exp Immunol, 2009, 157 Suppl 1, 3-11. DOI: 10.1111/j.1365-2249.2009.03954.x

66. Conley, M.E.; Dobbs, A.K.; Farmer, D.M.; Kilic, S.; Paris, K.; Grigoriadou, S.; CoustanSmith, E.; Howard, V.; Campana, D. Primary B cell immunodeficiencies: comparisons and contrasts, Annu Rev Immunol, 2009, 27, 199227.

DOI: 10.1146/annurev.immunol.021908.1326 $\underline{49}$

67. Bonilla, F.A.; Bernstein, I.L.; Khan, D.A.; Ballas, Z.K.; Chinen, J.; Frank, M.M.; Kobrynski, L.J.; Levinson, A.I.; Mazer, B.; Nelson, R.P., Jr.; Orange, J.S.; Routes, J.M.; Shearer, W.T.; Sorensen, R.U.; American Academy of Allergy, Asthma and Immunology; American College of Allergy, Asthma and Immunology; Joint Council of Allergy, Asthma and Immunology. Practice parameter for the diagnosis and management of primary immunodeficiency, Ann Allergy Asthma Immunol, 2005, 94 (5 Suppl 1), S163. DOI:10.1016/S1081-1206(10)61142-8

68. Chear, C.T.; Gill, H.K.; Ramly, N.H.; Dhaliwal, J.S.; Bujang, N.; Ripen, A.M.; Mohamad, S.B. A novel Bruton's tyrosine kinase gene (BTK) invariant splice site mutation in a Malaysian family with X-linked agammaglobulinemia, Asian Pac J Allergy Immunol, 2013, 31 (4), 320-324. DOI: 10.12932/AP0304.31.4.2013

69. Yazdani, R.; Hakemi, M.G.; Sherkat, R.; Homayouni, V.; Farahani, R. Genetic defects and the role of helper T-cells in the pathogenesis of common variable immunodeficiency, Adv Biomed Res, 2014, 3, 2. DOI: $10.4103 / 2277-9175.124627$

70. Notarangelo, L.D. Combined immunodeficiencies with nonfunctional $\mathrm{T}$ lymphocytes, Adv Immunol, 2014, 121, 12190. DOI:10.1016/B978-0-12-8001004.00004-0

71. Levenson, D. Higher prevalence of immune deficiency syndrome found in infants: Study finds nearly twice as many newborns affected by severe combined immunodeficiency than previous research had estimated, Am J Med Genet A, 2014, 164 (12), vii-viii. DOI: 10.1002/ajmg.a.36868 
72. Villa, A.; Santagata, S.; Bozzi, F.; Giliani, S.; Frattini, A.; Imberti, L.; Gatta, L. B.; Ochs, H. D.; Schwarz, K.; Notarangelo, L.D.; Vezzoni, P.; Spanopoulou, E. Partial V(D)J recombination activity leads to Omenn syndrome, Cell, 1998, 93 (5), 885-896. DOI:10.1016/S0092-8674(00)81448-8

73. Giliani, S.; Bonfim, C.; de Saint Basile, G.; Lanzi, G.; Brousse, N.; Koliski, A.; Malvezzi, M.; Fischer, A.; Notarangelo, L.D.; Le Deist, F. Omenn syndrome in an infant with IL7RA gene mutation, J Pediatr, 2006, 148 (2), 272274. DOI:10.1016/j.jpeds.2005.10.004

74. Chaigne-Delalande, B.; Li, F.Y.; O'Connor, G.M.; Lukacs, M.J.; Jiang, P.; Zheng, L.; Shatzer, A.; Biancalana, M.; Pittaluga, S.; Matthews, H.F.; Jancel,T.J.; Bleesing, J.J.; Marsh, R.A.; Kuijpers, T.W.; Nichols, K.E.; Lucas, C.L.; Nagpal, S.; Mehmet, H.; Su, H.C.; Cohen, J.I.; Uzel, G.; Lenardo M.J. $\mathrm{Mg} 2+$ regulates cytotoxic functions of $\mathrm{NK}$ and CD8 T cells in chronic EBV infection through NKG2D, Science ,2013, 341 (6142), 186-191. DOI: 10.1126/science.1240094

75. Slatter, M.A.; Gennery, A.R. Clinical immunology review series: an approach to the patient with recurrent infections in childhood, Clin Exp Immunol, 2008, 152 (3), 389-396. DOI: 10.1111/j.1365-2249.2008.03641.x

76. Lanternier, F.; Cypowyj, S.; Picard, C.; Bustamante, J.; Lortholary, O.; Casanova, J.L.; Puel, A. Primary immunodeficiencies underlying fungal infections, Curr Opin Pediatr, 2013, 25 (6), 736-747. DOI: 10.1097/MOP.0000000000000031

77. Abraham, R.S. Relevance of laboratory testing for the diagnosis of primary immunodeficiencies: a review of case-based examples of selected immunodeficiencies, Clin Mol Allergy, 2011, 9, 6. DOI:10.1186/1476-7961-9-6

78. Goldblatt, D. Recent advances in chronic granulomatous disease, $J$ Infect, 2014, pii: S0163-4453 (14), 00225-4. DOI: 10.1016/j.jinf.2014.07.013.

79. Minegishi, Y. Hyper-IgE syndrome, Curr Opin Immunol, 2009, 21 (5), 487-492. DOI:10.1016/j.coi.2009.07.013
80. Uzel, G.; Tng, E.; Rosenzweig, S.D.; Hsu, A.P.; Shaw, J.M.; Horwitz, M.E.; Linton, G.F.; Anderson, S.M.; Kirby, M.R.; Oliveira, J.B.; Brown, M.R.; Fleisher, T.A.; Law, S.K.; Holland, S.M. Reversion mutations in patients with leukocyte adhesion deficiency type-1 (LAD-1), Blood, 2008, 111 (1), 209218. DOI: http://dx.doi.org/10.1182/blood2007-04-082552

81. Bryan, A.R.; Wu, E.Y. Complement deficiencies in systemic lupus erythematosus, Curr Allergy Asthma Rep, 2014, 14 (7), 448. DOI: $10.1007 / \mathrm{s} 11882-014-0448-2$

82. Belderbos, M.; Levy, O.; Bont, L. Neonatal innate immunity in allergy development, $\mathrm{Curr}$ Opin Pediatr, 2009, 21 (6), 762-769. DOI: 10.1097/MOP.0b013e3283325e3a

83. Miller, R.L.; Chew. G.; Bell, C.; Biedermann, S.; Aggarwal, M.; Kinney, P.; Tsai, W.; Whyatt, R.; Perera, F.; Ford, J. Prenatal exposure, maternal sensitization, and sensitization in utero to indoor allergens in an inner-city cohort, Am J Respir Crit Care Med, 2001, $164 \quad$ (6), 995-1001. DOI: 10.1164/ajrccm.164.6.2011107

84. Jones, C.; Holloway, J.; Popplewell, E.; Diaper, N.; Holloway, J.;Vance, G.; Warner, J.; Warner, J. Reduced soluble CD14 levels in amniotic fluid and breast milk are associated with the subsequent development of atopy, eczema, or both, J Allergy Clin Immunol, 2002, $\quad 109 \quad$ (5), 858-866. DOI:10.1067/mai.2002.123535

85. Senthilselvan, A.; Renine, D.; Chénard, L.; Burch, L.; Babiuk, L.; Schwartz, D.; Dosman, J. Association of polymorphisms of toll-like receptor 4 with a reduced prevalence of hay fever and atopy, Ann Allergy Asthma Immunol, 2008, 100 (5), 463-468. DOI:10.1016/S1081-1206(10)60472-3

86. Lauener, R.; Birchler, T.; Adamski, J.; BraunFahrländer, C.; Bufe, A.; Herz, U.; von Mutius, E.; Nowak, D.; Riedler, J.; Waser, M.; Sennhauser, F.H.; ALEX study group. Expression of CD14 and Toll-like receptor 2 in farmers' and non-farmers' children, Lancet. 2002, $360 \quad$ (9331), 465-466. DOI:10.1016/S0140-6736(02)09641-1 
87. Ege, M.; Bieli, C.; Frei, R.; van Strien, R.; Riedler, J.; Ublagger, E.; Schram-Bijkerk, D.; Brunekreef, B.; van Hage, M.; Scheynius, A.; Pershagen, G.; Benz, M.; Lauener, R.; von Mutius, E.; Braun-Fahrländer, C.; Parsifal Study team. Prenatal farm exposure is related to the expression of receptors of the innate immunity and to atopic sensitization in school-age children, J Allergy Clin Immunol, 2006, $117 \quad$ (4), 817-823. DOI:10.1016/j.jaci.2005.12.1307

88. Ling, E.; Smith, T.; Nguyen, X.D.; Pridgeon, C.; Dallman, M.;Arbery, J.; Carr, V.A.; Robinson D. Relation of CD4+CD25+ regulatory $\mathrm{T}$-cell suppression of allergendriven $\mathrm{T}$-cell activation to atopic status and expression of allergic disease, Lancet, 2004, 363 (9409), 608-615. DOI:10.1016/S01406736(04)15592-X

89. Hyde, M.; Modi, N. The long-term effects of birth by caesarean section: the case for a randomised controlled trial, Early Hum Dev, 2012, $88 \quad$ (12), $943-949$. DOI:10.1016/j.earlhumdev.2012.09.006

90. Schaub, B.; Liu, J.; Höppler, S.; Schleich, I.; Huehn, J.; Olek, S.; Wieczorek, G.; Illi, S.; von Mutius, E. Maternal farm exposure modulates neonatal immune mechanisms through regulatory $\mathrm{T}$ cells, $J$ Allergy Clin Immunol, 2009, 123 (4), 771-782. DOI:10.1016/j.jaci.2009.01.056
91. Munblit, D.; Boyle, R.J.; Warner, J.O. Factors affecting Breast Milk composition, and potential consequences for development of the allergic phenotype, Clin Exp Allergy, 2014 Jul 31, [Epub ahead of print]. DOI: $10.1111 /$ cea.12381

92. Abbas, A.; Benoist, C.; Bluestone, J.; Campbell, D.; Ghosh, S.; Hori, S.; Jiang, S.; Kuchroo, V.K.; Mathis, D.; Roncarolo, M.; Rudensky, A.; Sakaguchi, S.; Shevach, E.; Vignali, D.; Ziegler, S. Regulatory T cells: recommendations to simplify the nomenclature, Nat Immunol, 2013, 14 (4), 307-308. DOI:10.1038/ni.2554

93. Schade, R.; van Ieperen-Van Dijk, A.G.; van Reijsen, F.; Versluis, C.; Kimpen, J.; Knol, E.; Bruijnzeel-Koomen, C.; van Hoffen, E. Differences in antigen-specific T-cell responses between infants with atopic dermatitis with and without cow's milk allergy: relevance of TH2 cytokines, J Allergy Clin Immunol, 2000, 106 (6), 1155-1162. DOI:10.1067/mai.2000.110802

94. Järvinen, K.; Westfall, J.; Seppo, M.; James, A.; Tsuang, A.; Feustel, P.; Sampson, H.; Berin, C. Role of maternal elimination diets and human milk IgA in the development of cow's milk allergy in the infants, Clin Exp Allergy, 2014, 44 (1), 69-78. DOI: $10.1111 /$ cea.12228 